\title{
UPAYA PENINGKATAN KUALITAS KOMPETENSI GURU MELALUI WORKSHOP DI MADRASAH TSANAWIYAH KOTA MALANG
}

\author{
Galuh Ayu Noviyantika \\ Universitas Negeri Malang, Jalan Semarang 5 Malang 65I45 \\ Email: gangaluh@gmail.com
}

\begin{abstract}
Abstrak: Ada empat kompetensi yang harus dimiliki oleh guru, kompetensi-kompetensi tersebut adalah kompetensi pedagogik, kompetensi kepribadian, kompetensi sosial, dan kompetensi profesional. Salah satu upaya peningkatan kualitas kompetensi guru adalah melalui kegiatan workshop. Penelitian ini bertujuan untuk mengetahui efek yang diberikan oleh kegiatan workshop kepada para guru di madrasah. Penelitian kualitatif yang digunakan dalam pengamatan ini, teknik yang digunakan adalah wawancara dan observasi mendatangi lokasi sekolah. Berdasarkan dari hasil penelitian maka dapat diketahui bahwa kegiatan workshop adalah sebagai penunjang untuk guru-guru dalam meningkatkan kompetensinya.
\end{abstract}

Kata Kunci: kompetensi, kualitas, workshop

Abstract: There are four competencies that must be possessed by the teacher, these competencies are pedagogic competence, personality competence, social competence, and professional competence. One effort to improve the quality of teacher's competencies is through workshop activities. This study aims to find out the effects of the workshop activities on teachers at the school. Qualitative research used in this observation, the techniques used are interviews and observations coming to the location of the school. Based on the results of the study, it can be seen that the workshop is a support for teachers in improving their competence.

Keywords: competencies, quality, workshop

\section{PENDAHULUAN}

Guru merupakan tulang punggung dari sistem pendidikan dan hal tersebut telah diakui secara universal dikarenakan pengetahuan yang didapatkan oleh siswa melalui dari guru (Malik $\mathrm{dkk}, 20 \mathrm{Il})$. Kemudian, peran dari seorang guru adalah menciptakan suasana yang nyaman untuk siswanya dan mendorong ataupun memotivasi segala yang dilakukan siswanya secara positif (Moustofa, 20I3). Keiler (20I8) juga menjelaskan bahwa guru dianjurkan menggunakan cara mengajar yang berpusat pada siswa dalam menghadapi tantangan zaman. Guru dan siswa akan berinteraksi di dalam kelas dalam menyerap dan menggali pengetahuan dan infromasi dengan melalui beberapa proses yaitu dianataranya adalah mengeksplorasi, menalar, tanya jawab, menemukan, dan mengelaborasi dalam memecahkan permasalahan tentang pembelajaran di kelas. Oleh karena itu, dalam pelaksanaan tugas dan keprofesiannya, guru merupakan seorang manajer di dalam kelas untuk mewujudkan proses belajar pembelajaran yang aktif, inovatif, dan menyenangkan.

Terkait hal tersebut, terdapat undang-undang yang menyebutkan tentang kompetensi guru yang harus dimiliki oleh setiap guru. Undang-undang nomor 14 tahun 2005 tentang guru dan dosen pasal 10 ayat I menyebutkan empat kompetensi, diantaranya yaitu kompetensi pedagogik, kompetensi kepribadian, kompetensi profesional, dan kompetensi sosial. Sehubungan dengan hal tersebut, fungsi sebagai guru adalah mampu memiliki kompetensi berwujud pengetahuan dan keprofesionalan. Oleh karena itu, guru yang handal merupakan guru yang berkapasitas memiliki kompeten dan profesionalitas tinggi dalam menjalankan profesinya. Dengan demikian, kualitas guru menunjukkan sebagai rahasia kesuksesan sistem pendidikan yang berkualitas. 
Pidarta (2009) berpendapat bahwa guru adalah pribadi yang selalu berusaha untuk mengembangkan dirinya. Apabila guru dapat beradaptasi terhadap setiap perkembangan maka setiap proses pembelajaran di kelas akan lebih terarah dan memberikan suatu kepuasan terhadap prestasi siswa. Disisi lain, tidak semua guru dapat menerapkannya dengan berbagai kendala sehingga mengakibatkan kinerja guru rendah. Dengan begitu diperlukannya suatu kegiatan untuk memecahkan permasalahan tersebut. Selama ini, pemerintah Indonesia telah mewujudkan beberapa kegiatan sebagai alternatif pemecahan masalah yang terjadi melalui berbagai program seperti Kelompok Kerja Guru (KKG), Kegiatan Musyawarah Guru Mata Pelajaran (MGMP), pelatihan diklat, supervisi, dan workshop.

Fenomena yang terjadi saat ini adalah tugas guru begitu kompleks, selain itu tidak menutup kemungkinan seorang guru juga dituntut untuk selalu update tentang pengetahuan, informasi, dan wawasan terbaru dalam mengembangkan profesinya. Melalui kegiatan workshop, para guru akan dibimbing dan diasah kemampuannya dalam mengembangkan profesinya. Sasaran kegiatan workshop disini adalah guru dalam pembelajaran sebagai peningkatan mutu kompetensi dalam mengajar. Kegiatan workshop akan membekali para guru untuk belajar mengenai mulai dari menyusun perangkat pembelajaran sampai dengan mengembangkan pembelajaran yang akan ditransfer kepada siswa dalam kegiatan belajar mengajar di kelas. Kegiatan workshop dapat dikatakan sebagai pendidikan berkelanjutan bagi guru, dikarenakan pengembangan profesional guru memerlukan suatu pembelajaran berkelanjutan (Boudersa, 2016).

Demikian halnya MTs Sunan Kalijogo Malang dalam menjaga sekaligus meningkatkan kualitas guru disana, maka kepala sekolah dan ketua yayasan berupaya mengadakan workshop semacam pembekalan untuk para guru dalam mengembangkan kompetensi. Hal tersebut bertujuan agar guru dibekali suatu keahlian dalam mengembangkan pembelajaran di kelas, disisi lain melalui kegiatan tersebut maka guru difasilitasi untuk saling bertukar ide dalam memecahkan permasalahan yang sedang dihadapi. Berdasarkan dari pemaparan di atas, maka peneliti melakukan pengamatan yang bertujuan untuk mengetahui efek yang didapatkan oleh guru setelah mengikuti kegiatan workshop.

\section{METODE}

Penelitian ini merupakan penelitian kualitatif dengan melakukan teknik pengumpulan data melalui observasi dan wawancara. Observasi tersebut dilakukan di MTS Sunan Kalijogo Kota Malang. Wawancara tersebut dilakukan peneliti dengan kepala sekolah MTS Sunan Kalijogo Malang dan waka kurikulum selaku pengkordinasi para guru di MTS Sunan Kalijogo. Selain itu, peneliti juga melalukan teknik dokumentasi untuk menggali informasi yang ada di MTS Sunan Kalijogo dan sebagai penguat bukti dari penelitian. Setelah melakukan beberapa teknik penelitian, maka peneliti melakukan analisis data terhadap data yang telah didapatkan. Peneliti menggunakan alur analisis data dari Moleong (2009), alur tersebut bermula dari menelaah semua data yang telah didapatkan oleh narasumber, kemudian mereduksi data, lalu menafsirkan data.

\section{HASIL DAN PEMBAHASAN Profil MTS Sunan Kalijogo}

MTS Sunan Kalijogo merupakan lembaga pendidikan yang beralamat di Jalan Candi 3 D No. 442. MTS Sunan Kalijogo merupakan madrasah tsanawiyah di bawah naungan yayasan taman pendidikan Islam "Sunan Kalijogo". Madrasah tersebut mempunyai akreditasi B sejak tahun 2016 hingga saat ini. MTS Sunan Kalijogo tersebut memiliki visi "Terciptanya Peserta Didik yang Berakhlak, Kreatif, Berbudaya”. Kemudian juga memiliki beberpa misi diantanya adalah; I) menumbuh kembangkan sikap dan alamiah islami, 2) mengembangkan pembelajaran berbasis iman dan taqwa, 3) menciptakan budaya gemar membaca, menulis dan berinteraksi, 
4) mengembangkan pembelajaran saintifik, 5) menumbuhkan semangat keunggulan dan kompetisi, 6) melaksanakan pembelajaran berbasis pengetahuan dan teknologi, 7) menciptakan suasana kelas yang indah, nuriah, dan faedah, 8) menumbuhkan kebanggaan dan kecintaan terhadap bangsa, bahasa, dan tradisi, 9) menciptakan komunikasi yang akrab dan santun. Dalam mewujudkan pembelajaran yang efektif, madrasah menggunakan Kurikulum Tingkat Satuan Pendidikan (KTSP) sebagai pengintegrasian pembelajaran.

\section{Peningkatan Kualitas Guru}

Kotler (2009) mendefinisikan tentang kualitas merupakan bagian dari keseluruhan dari sifat dan ciri suatu barang maupun jasa yang berimbas pada kemampuan yang telah dianggap mampu dalam memenuhi kebutuhan. Sebagai seorang profesi guru, maka guru memiliki dua tugas yaitu sebgai pengajar dan pendidik (Natsir, 2007). Oleh karena itu, guru yang berkualitas dapat dikatakan bahwa guru yang telah memiliki kemampuan dalam mencapai standar kompetensi. Peningkatan kualitas guru merujuk pada kompetensi yang dimilikinya dalam mengelola pembelajaran di kelas penuh tanggung jawab. Kualitas guru dikatakan baik jika guru telah mempunyai cara berpikir penuh dengan kekreatifan, menyenangkan, inovatif, dan terampil dalam segala hal kebaikan. Berpikir secara kreatif dan penuh inovasi perlu dimiliki oleh guru, hal tersebut disebabkan karena dalam mengembangkan proses pembelajaran di sekolah membutuhkan dua aspek tersebut.

Beberapa penelitian mengatakan bahwa kualitas guru ditunjukkan melalui kompetensi guru yang berpengaruh pada kualitas pendidikan (Permana, 2017). Kemudian Yusutria (2017) juga berpendapat bahwa yang menentukan pendidikan berkualitas dapat dilihat dari tiga komponen yaitu input, proses, dan output. Akan tetapi yang menajadi ujung tombaknya yaitu guru, disebabkan guru yang akan menyampaikan segala wawasan ilmu yang berisi mata pelajaran kepada peserta didik. Setiap pembelajaran di kelas tentu saja memiliki tujuan pembelajaran, oleh karena itu guru perlu merencanakan langkah-langkah dengan matang. Adapun langkahlangkah tersebut dimulai dengan perencanaan, pengkoordinasian, pelaksanaan, dan pengevaluasian. Dengan demikian, guru dituntut untuk memperbaiki kualitasnya dalam mencapai kepuasan dari segi internal maupun eksternal.

Fenomena yang terjadi pada MTS Sunan Kalijogo Malang yaitu bahwa ada beberapa guru yang harus meningkatkan kompetensinya dari segi kompetensi pedagogik, kompetensi profesional, kompetensi kepribadian, dan kompetensi sosial. Hal tersebut akan dijabarkan lebih jelasnya pada tabel di bawah ini:

Tabel I Jumlah Guru yang harus Meningkatkan Kompetensi

\begin{tabular}{|l|l|l|}
\hline No & Jenis Kompetensi & Jumlah Guru \\
\hline I & Kompetensi Pedagogik & 8 \\
\hline 2 & Kompetensi Kepribadian & 8 \\
\hline 3 & Kompetensi Profesional & 8 \\
\hline 4 & Kompetensi Sosial & 8 \\
\hline
\end{tabular}

Berdasarkan dari data dari madrasah, jumlah guru yang berada di MTS Sunan Kalijogo adalah 21 orang guru. Demikian halnya dari tabel di atas, maka dapat disimpulkan bahwa jumlah guru yang belum mencapai dari empat kategori kompetensi yaitu sebanyak $38 \%$. Hal tersebut ditemukan dari $\frac{8}{21} \times 100 \%=38,1 \%$

\section{Upaya Peningkatan Kualitas Melalui Workshop}

Berdasarkan dari hasil observasi dan pengamatan melalui wawancara pada MTS Sunan Kalijogo Malang menunjukkan bahwa kegiatan workshop merupakan usaha perbaikan kualitas yang sangat dominan dilakukan. Ketua yayasan dan kepala sekolah madrasah begitu open untuk para guru dalam mengembangkan kompetensinya. Pada jam istirahat, atau saat kepala sekolah sedang berada di madrasah selalu menyempatkan untuk ke ruang guru untuk berdiskusi kecil 
dengan para guru untuk melakukan evaluasi. Apabila terdapat suatu permasalahan, kepala sekolah selaku dokter yang dapat menyembuhkan penyakit yang ada di dalam diri guru memberikan suatu saran terhadap guru tersebut dalam pemecahan permasalahan tersebut. Akan tetapi, saran tersebut tidak semata-mata langsung ditelan mentah-mentah oleh guru tersebut, tetapi kepala sekolah dan guru tersebut saling bertukar pendapat untuk mencapai suatu kebaikan yang diinginkan.

Ibu Eny selaku waka kurikulum menerangkan bahwa guru-guru yang berada di MTS Sunan Kalijogo telah memenuhi kualifikasi yaitu telah bersarjana SI. Saat ini madrasah masih menggunakan kurikulum KTSP, akan tetapi madrasah memiliki keinginann untuk mengembangkan kurikulum pembelajaran ke kurikulum 2013. Namun, keadaan saat ini masih menjelaskan bahwa masih perlu adanya banyak perbaikan terhadap kualitas sekolah. Salah satunya adalah tetap mempertahankan dan meningkatkan kualitas guru. Kepala sekolah madrasah juga menjelaskan bahwa upaya sekolah dalam memperbaiki kualitas guru selain melalui workshop juga bekerja sama dengan pihak universitas sebagai rekan pengembang sekolah. Kepala sekolah menjelaskan bahwa madrasah bekerja sama dengan UIN Maulana Malik Ibrahim sebagai tim pengembang, dan penyedia sumber daya manusia.

lbu Eny menerangkan bahwa permasalahan yang dijumpai sampai saat ini adalah guru yang mengalami kesusahan dalam mengembangkan RPP dan silabus. Untuk mempertahankan dan terus melakukan perbaikan dalam menjaga kualitas guru, maka kepala madrasah dengan ketua yayasan telah berkoordinasi untuk menyelenggarakan kegiatan workshop sebagai penunjangan perbaikan kualitas guru. Dalam kegiatan workshop tersebut, pihak madrasah mengundang pakar untuk diundang sebagai narasumber. Disisi lain, pemerintah sebenarnya sudah memfasilitasi para guru untuk mengembangkan kompetensinya sebagai contoh melalui KKG, MGMP, dan pelatihan-pelatihan melalui dinas kota. Namun, pihak madrasah percaya bahwa kegiatan workshop menjadi satu alternatif untuk pemecahan masalah tentang peningkatan kualitas kompetensi guru.

Kemudian ibu Eny selaku waka kurikulum dan pengkordinasi seluruh guru di madrasah menyatakan bahwa apabila workshop telah dilaksanakan, guru-guru di madrasah seperti mendapatkan suatu semangat baru. Dengan begitu, guru-guru madrasah semangat untuk membuat RPP dan ingin mencoba mengembangkan silabus juga. Namun, kalau sudah jangkanya agak lama dari kegiatan workshop, guru-guru madrasah kembali seperti kekurangan semangat lagi. Oleh karena itu, pihak madrasah juga memfasilitasi para guru yang ingin mengikuti workshop di luar penyelenggaraan dari madrasah. Hal tersebut dilakukan secara berkala dan pihak madrasah selalu mendukung apa yang dikerjakan guru untuk mencapai tujuan pembelajaran yang maksimal. Demikian halnya, kegiatan workshop tersebut juga terdapat evaluasinya untuk menindak lanjuti apakah kegiatan workshop tersebut dapat berkontribusi dengan baik.

\section{KESIMPULAN}

Kualitas merupakan suatu karakteristik secara keseluruhan yang mengarah pada kemampuan yang dapat mencapai suatu pemenuhan kebutuhan.Melalui hasil pengamatan di MTS Sunan Kalijogo Malang, dalam menjaga kualitas kompetensi guru disana maka madrasah mengadakan suatu workshop secara berkala untuk perbaikan kualitas guru disana. Dengan demikan, workshop dapat mempermudah guru dalam mengembangkan kompetensinya menjadi lebih baik. Workshop tersebut juga dipandu oleh para pakarnya, kemudian kegiatan tersebut juga dievaluasi untuk melihat sejauh mana kegiatan tersebut dapat berkontribusi. Disisi lain, kegiatan workshop juga dapat meningkatkan semangat guru, karena para guru disana seperti mendapatkan suatu inovasi baru dalam mengembangkan kompetensinya. 


\section{DAFTAR RUJUKAN}

Boudersa, Nassira. (2016). The Importance of Teachers' Training Programs and Professional Development in the Algerian Educational Context: Toward Informed and Effective Teaching Practices. ResearcheGate, (I).

Keiler, L. S. (2018). Teachers' roles and identities in student-centered classrooms. International Journal of STEM Education, 5(I).

Kotler, Philip. (2009). Manajemen Pemasaran Edisi 13. Jakarta: Erlangga

Malik, M. A., Murtaza, Ali., \& Khan, A. M. (20II). Role of Teachers in Managing Teaching Learning Situation. INTERDISCIPLINARY JOURNAL OF CONTEMPORARY RESEARCH IN BUSINESS, 3(5).

Moleong, Lexy J. (2009). Metode Penelitian Kualitatif. Bandung: Remaja Rosdakarya

Moustafa, A., Ben-Zvi-Assaraf, O., \& Eshach, H. (2013). Do junior high school students perceive their learning environment as constructivist? Journal of Science Education and Technology, 22(4), 4I8-43I.

Natsir, Nanat F. (2007). Peningkatan Kualitas Guru dalam Perspektif Pendidikan Islam. EDUCATIONIST, I I I).

Pidarta, Made. (2009). Supervisi Pendidikan Kontekstual. Jakarta: Rineka Cipta

Permana, Nana .S. (2017). Peningkatan Mutu Tenaga Pendidik Dengan Kompetensi dan Sertifikasi Guru. STUDIA DIDAKTIKA: Jurnal Ilmiah Bidang Pendidikan, II (I).

Yusutria. (2017). Profesionalisme Guru Dalam Meningkatkan Kualitas Sumber Daya Manusia. Jurnal Curricula, 2(I). 